\title{
EFFECTS OF ALPHA, BETA MOMORCHARIN FRUIT EXTRACT WITH THE COMBINATION OF PACLITAXEL IN THE TREATMENT OF GLIOMA CANCER IN-VIVO
}

\author{
Gunasekar Manoharan
}

Chemistry Department, Faculty of Science, Jazan University, Al-Rawda District, Jazan, Saudi Arabia.

\begin{abstract}
The vegetable Momordica Charantia L., (family: Cucurbitaceae) is a scientific name of the plant and its fruit. It is also known by other names, for instance in the USA it is known as Bitter gourd or balsam pear while its referred to as the African cucumber in many African countries. M. Charantia is believed to posse's anti-carcinogenic properties and it can modulate its effect via xenobiotic metabolism and oxidative stress. This study was specifically designed to investigate the cellular mechanisms whereby $\alpha, \beta$ momorcharin an extract of $M$. Charantia can induce cell death with the combination of paclitaxel. Different concentration $(200 \mu \mathrm{M}-1000 \mu \mathrm{M})$ of the $\alpha, \beta$ momorcharin fruit extract were treated (24 hrs. incubation) separately with three different cancer cell lines 1321N1, Gos-3, U87-MG and normal L6 muscle cell line. The results also show that paclitaxel $(250 \mu \mathrm{g})$ with $(1000 \mu \mathrm{M})$ of the $\alpha, \beta$ momorcharin extract of $M$. Charantia, and result in significant decreases in cell viability for each cell line, these effects were additive compared to the individual effect of paclitaxel.
\end{abstract}

Keywords: Cancer cell lines, $\alpha, \beta$ momorcharin extract of $M$. Charantia and paclitaxel (PAT).

\section{Introduction}

The water-soluble extract of the $M$. Charantia can significantly reduce blood glucose concentrations in type-1 diabetic rats [1]. Several studies have reported that the water-soluble extract of $M$. Charantia can exert anticancerous activity through inhibition of DNA, RNA and cellular protein synthesis [2-4]. The fruit juice of $M$. Charantia has been found to increase glucose up take by several tissues in vitro and moreover, it can increase the storage of glycogen by the liver [5,6]. Paclitaxel is a natural product with antitumor activity. Paclitaxel is a diterpene alkaloid derived from the dried bark of Pacific yew tree Taxus brevifolia [7-9]. The chemical name for paclitaxel is $5 \beta, 20$-Epoxy-1, 2 $\alpha, 4,7 \beta, 10 \beta, 13 \alpha-$ hexahydroxytax-1 1-en-9-one 4,10-diacetate 2-benzoate 13-ester with $(2 R, 3 S)-N$-benzoyl-3-phenylisoserine. Paclitaxel is a white to off-white crystalline powder with the empirical formula $\mathrm{C}_{47} \mathrm{H}_{51} \mathrm{NO}_{14}$ and a molecular weight of $853.9 \mathrm{~g} / \mathrm{mol}[9,10]$. Paclitaxel is highly lipophilic, and melts at around $216-217^{\circ} \mathrm{C}$ and is used in treatment of various advanced carcinomas such as ovarian cancer, lung cancer, breast cancer, acute leukemias, head and neck cancers and Kaposi's sarcoma [11-13]. Paclitaxel is a mitotic inhibitor that blocks the proliferation of cancer celland is commercially available as Tax$\mathrm{ol}^{\circledR}$ that consists of Paclitaxel solubilised in Cremophor EL (polyethoxylated castor oil) and dehydrated alcohol $(1: 1 \mathrm{v} / \mathrm{v})$ [14-16]. Unfortunately, severe adverse reactions like hypersensitivity reactions are caused by Cremophor EL [17-19].

eISSN: 2523-6709

pISSN: $2523-6695$

DOI: $10.31878 /$ ijcrpp.2019.32.1

\section{Materials and Methods}

Extraction method for either of $\alpha$ or $\beta$ momorcharin: The whole fruit of bitter gourd was ground and homogenized in $2 \mathrm{mM}$ sodium phosphate buffer, $\mathrm{pH} 7.5$. The resulting slurry was then stirred for $3 \mathrm{hrs}$ to extract the crude proteins. The insoluble component from crude proteins was removed by the filtration and centrifugation at $30,000 \times \mathrm{g}$ for 1 hour at $48^{\circ} \mathrm{C}$. By using $2 \mathrm{mM}$ sodium phosphate buffer, $\mathrm{pH} 7.5$, the crude protein solution was dialysed. The dialysed protein sample was applied to DEAE Sepharose column equilibrated with 2 $\mathrm{mM}$ sodium phosphate buffer at $\mathrm{pH}$ 7.5. The unbound proteins were then applied to Mono-S column which was equilibrated by $2 \mathrm{mM}$ sodium phosphate buffer at $\mathrm{pH} 7.5$ and eluted by $0.5 \mathrm{~m}$ of $\mathrm{NaCl}$. [20]. The fraction corresponding to either alpha and beta or alpha, beta momorcharin, which was confirmed the N-glycoside activity RNA, was concentrated and dialysed against 20 $\mathrm{mM}$ Tris-HCl buffer, $\mathrm{pH}$ 7.8. The chromatography was performed on Bio Logic DuoFlow system (BioRad, Hercules, CA) at $48^{\circ} \mathrm{C}$. The purity of $\alpha$ and $\beta$ momorcharin was examined by SDS-PAGE and gel filtration chromatography. The concentration of alpha momorcharin was determined by spectrophotometrically using optical absorbance at $280 \mathrm{~nm}$.

\section{Passaging of the Cancer cell lines and Control cell} line

The culture medium, phosphate buffer solution (PBS), and trypsin (sterile) were removed from the fridge at $4^{\circ} \mathrm{C}$ and subsequently placed in the water bath at $37^{\circ} \mathrm{C}$ for $30 \mathrm{~min}$ in order to equilibrate. The Laminar flow hood was turned on for $15 \mathrm{~min}$, prior to start of the experiment, in order to purge the air inside the cabinet and to reach the maximum cleanliness.

Correspondence: Dr. Gunasekar Manoharan, Chemistry Department, Faculty of Science, Jazan University, Al-Rawda District, Jazan, Saudi Arabia. Email: shekarphd@yahoo.com 
Three different cancer cell lines (1321N1, Gos-3, U87$\mathrm{MG})$ and L6 normal cell lines were incubated at $37^{\circ} \mathrm{C}$ incubator in an atmosphere of $5 \% \mathrm{CO}_{2}$ in air. The cells were examined under the inverted contrast microscope to note the both confluence and general health of the cells. The flask was passaged when the cells had reached $70-80 \%$ confluence. The medium was aspirated from the cultured flask and was washed with sterile PBS ( $5 \mathrm{ml}$ if $75 \mathrm{~cm}^{2}$ flask and $2 \mathrm{ml}$ if $25 \mathrm{~cm}^{2}$ flask) in order to remove any traces of serum from the cells. This prevented the serum from inactivating the trypsin, which was used to detach adherent cells from the cell clump. Trypsin solution ( $2 \mathrm{ml}$ if $75 \mathrm{~cm}^{2}$ flask or $1 \mathrm{ml}$ if $25 \mathrm{~cm}^{2}$ flask) was pipetted in the flask and incubated at $37^{\circ} \mathrm{C}$ in an incubator in an atmosphere of $5 \% \mathrm{CO}_{2}$ in air for 3-5 mins until the cells began to detach. The detachment was confirmed by observing at intervals under an inverted microscope. The cells were left in the trypsin solution for the correct length of time. If the cells were left for a longer period of time then this would lead to damage of the cells. A volume of $3 \mathrm{ml}$ complete growth medium was then added to the flask to inactivate the trypsin and the cells were pipetted up and down to break up any large cell aggregates. The cell suspension was transferred from flask into $15 \mathrm{ml}$ centrifuge tube and centrifuged at $1000 \mathrm{rpm}$ for $5 \mathrm{~min}$. Following centrifugation, the supernatant was aspirated and the cells were pellet at the bottom of the centrifuge tube. Based upon the cell pellet density volumes of $1 \mathrm{ml}$ to $3 \mathrm{ml}$ fresh medium were suspended in the centrifuge tube. The cell pellet was flicked properly in the medium containing 20 $\mu l$ of trypsinised cell suspension and $80 \mu$ l of tryphan blue (used to detect dead cells in the cell suspension 1:5 ratio). The contents were mixed well together and a haemocytometer test was performed using $1 \mathrm{ml}$ of cell suspensions. This process helped to assess the total number of the cell suspension present in the centrifuge tube and which was required to make 1 or 2 flasks and to do 96 well plates. Thereafter, the cells were frozen in liquid nitrogen depending on the number of cells present per $\mathrm{ml}$. The cell suspension was divided in either one or several flasks (depending on the cell density) and fresh growth medium $\left(10 \mathrm{ml}\right.$ to $12 \mathrm{ml}$ if $75 \mathrm{~cm}^{2}$ flask and 5 $\mathrm{ml}$ if $25 \mathrm{~cm}^{2}$ flask) was added to the flasks. These were then placed in a $5 \% \mathrm{CO}_{2}$ incubation.

\section{Preparation and application of $\alpha, \beta$ momorcharin extracts of $M$. Charantia on the cancer and L6 cell lines.}

Amounts of $14.51 \mathrm{mg}, 29.25 \mathrm{mg}, 43.53 \mathrm{mg}, 58.50 \mathrm{mg}$, and $72.57 \mathrm{mg}$ of either alpha or beta momorcharin and alpha, beta momorcharins $(9.7 \mathrm{kDa})$ were weighed out separately in $5 \mathrm{ml}$ universal vials and initially dissolved in $500 \mu \mathrm{l}$ of phosphate buffer by continuous stirring and with the brief use of a sonicator water bath. These were then made up to $5 \mathrm{ml}$ by adding $4.5 \mathrm{ml}$ of the cell medium to give concentrations $200 \mu \mathrm{M}, 400 \mu \mathrm{M}, 600 \mu \mathrm{M}$, $800 \mu \mathrm{M}, 1000 \mu \mathrm{M}$, respectively. The drug (extract) stock solution was transferred to a $10 \mathrm{ml}$ syringe and sterile filtered using $0.22 \mu \mathrm{m}$ filters into another sterile $10 \mathrm{ml}$ Universal bottles. These stock solutions were stored in a sealed tube in the fridge until required. Once removed from the fridge the prepared drug (extract) solutions were gently warmed in water bath at $37^{\circ} \mathrm{C}$ in order to ensure that the alpha, beta momorcharins was in a complete solution, before aliquoting. Volumes of 40 $\mu \mathrm{l}, 80 \mu \mathrm{l}, 120 \mu \mathrm{l}, 160 \mu \mathrm{l}, 200 \mu \mathrm{l}$ contained $200 \mu \mathrm{M}, 400$ $\mu \mathrm{M}, 600 \mu \mathrm{M}, 800 \mu \mathrm{M}, 1000 \mu \mathrm{M}$, respectively. Different concentrations of alpha beta momorcharins were transferred in triplicate using a Gilson pipette to 96 wells plate and the volume made to $200 \mu \mathrm{l}$ by adding the cell media to both treated and control cell wells. Both control (untreated) and treated with (alpha beta momorcharin) 96 well plates were incubated for $24 \mathrm{hrs}$.

\section{Dose dependent effects of paclitaxel on cancer cell line viability.}

In this series of experiments, different cancer cell lines (1231N1, Gos-3, U87-MG) and healthy L6 muscle cell line were incubated with the different concentrations of paclitaxel $(50-250 \mu \mathrm{g})$ for 24 hours. Control cell lines were also incubated for the same period of time but without any paclitaxel. At the end of the incubation period, cell viability of each cell line was measured using the MTS assay.

\section{Combined effects of either paclitaxel with the $\alpha, \beta$ momorcharin extract of M. Charantia :}

Different cancer cell lines (1231N1, Gos-3, U87-MG) and healthy L6 muscle cell line were incubated either with paclitaxel $(250 \mu \mathrm{g})$ and the $\alpha, \beta$ momorcharin extract of $M$. Charantia $(1000 \mu \mathrm{M})$ or paclitaxel $(250 \mu \mathrm{g})$ and $1000 \mu \mathrm{M}$ ) of the alpha, beta momorcharin for 24 hours. Control cell lines were also incubated for the same time but without any drug or extract. At the end of the incubation period, cell viability of each cell line was measured using the MTS assay.

Statistical Analysis: All control and test data collected from the different experiments were analysed using Statistical Package for Social Sciences (SPSS) version 17, Student's t- test and ANOVA test. Data obtained were expressed as mean \pm standard deviation (S.D). Each experiment was repeated for 4-6 times in duplicate (6 for cell viability and 4 for cell signalling) to ensure the accuracy of results. A value of $(p<0.05)$ was taken as significant.

\section{Results}

\section{Dose-dependent effects of paclitaxel on cell viability}

Figure 1 shows the effects of different concentrations $(50-250 \mu \mathrm{g})$ of paclitaxel on the viability of the three different cancer cell lines and on healthy L6 skeletal muscle cell line employed in this study. Also shown in the figure 1 are the untreated three different cancer cell lines and healthy L6 skeletal muscle cell line for comparison. All the cells were treated with paclitaxel for 24 hours. Each control cell lines were also incubated for 24 hrs but with no paclitaxel. The results show that in all three different cancer cell lines (1321N1, Gos-3, U87$\mathrm{MG})$, paclitaxel can evoke marked and significant ( $\mathrm{p}<$ $0.05)$ decreases in the cell viability (cell death) compared to untreated cells (100\% viability). These effects of the paclitaxel were dose-dependent with maximal cell death occurring with $250 \mu \mathrm{g}$. Similarly, paclitaxel significantly $(\mathrm{p}<0.05)$ decreased the viability of healthy L6 skeletal muscle cell line compared to untreated L6 cell line but mainly at a high dose. The results also show that paclitaxel was more effective in killing 1321N1 and Gos-3, cell lines. It has less effective on U87-MG cell line, which seems to be more resistant to the drug. The surprised finding in this study was that paclitaxel could 


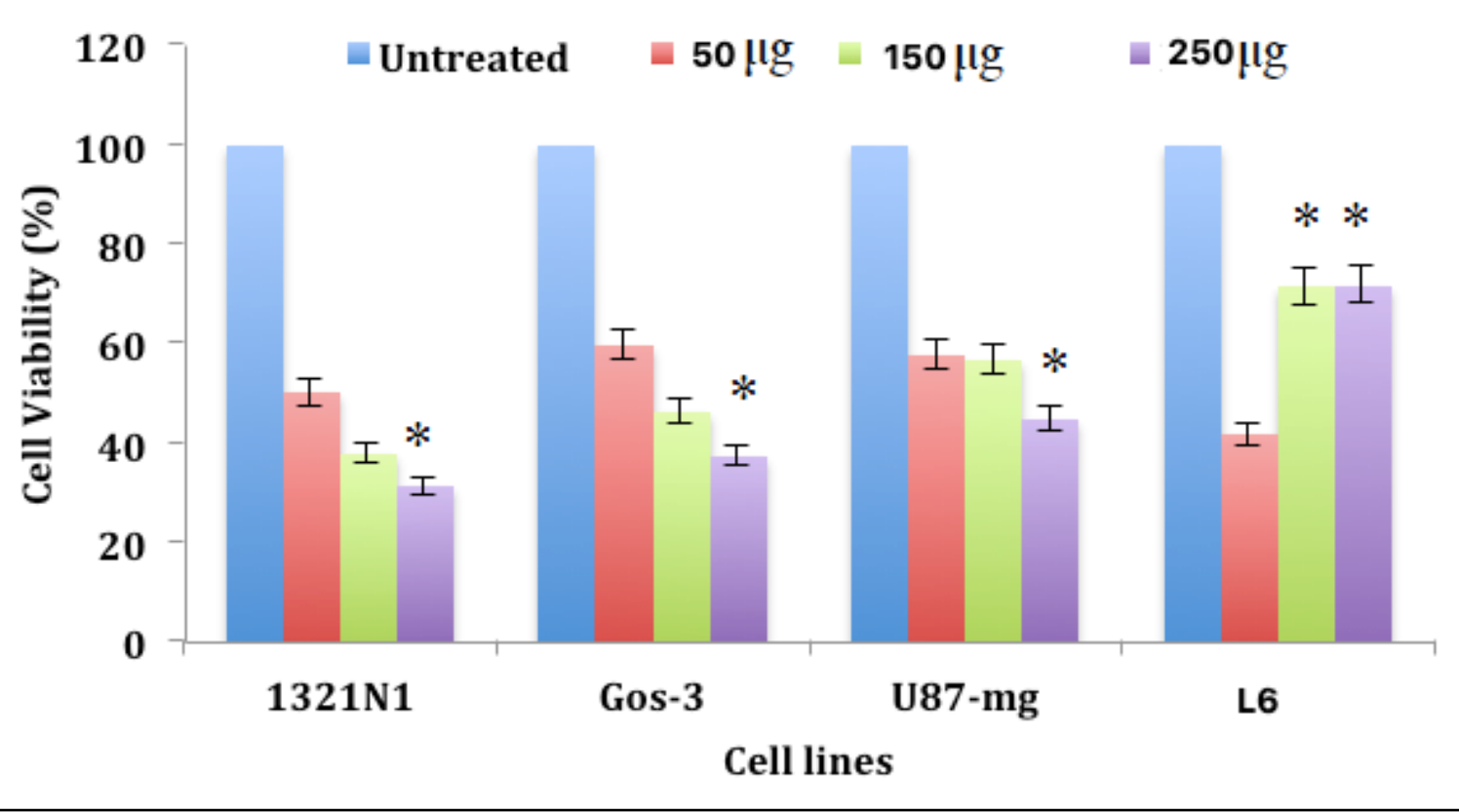

Figure 1. Dose-dependent effects of paclitaxel

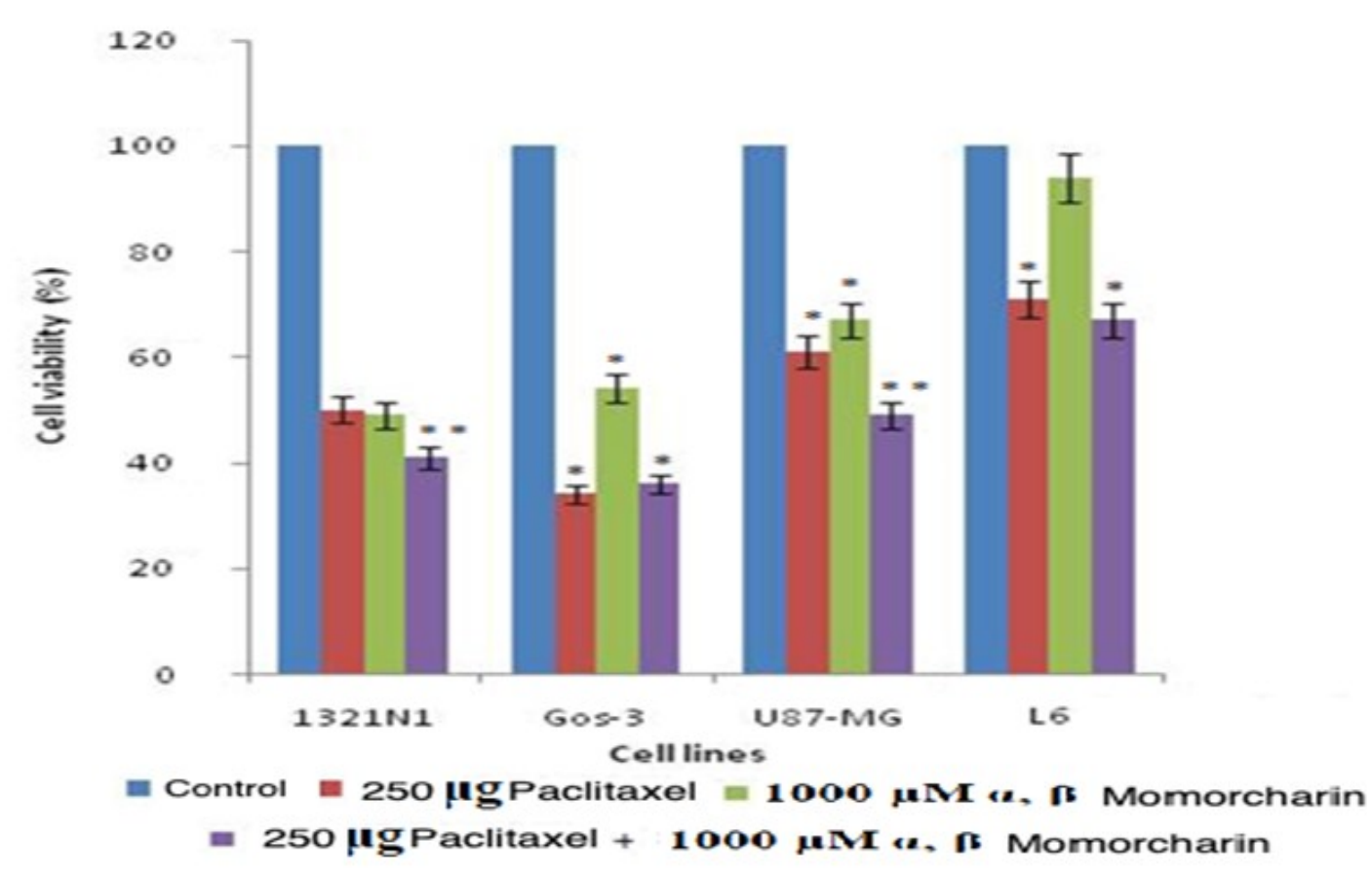

Figure 2. Effect of either of $250 \mu \mathrm{g}$ paclitaxel alone or $1000 \mu \mathrm{M}$ of $\alpha, \beta$ momorcharin of $M$. Charantia alone and combination of paclitaxel $(250 \mu \mathrm{g})$ with $\alpha, \beta$ momorcharin extract of $M$. Charantia $(1000 \mu \mathrm{M})$ on the viability of three different cancer cell lines

also kill healthy L6 skeletal muscle cell compared to the $\alpha, \beta$ momorcharin extract of $M$. Charantia, which had no detectable effect on the viability of L6 cell line.

\section{Combined effects of $\alpha, \beta$ momorcharin extract of $M$.} Charantia with paclitaxel

Figure 2 shows the effect of paclitaxel $(250 \mu \mathrm{g})$ alone or the $\alpha, \beta$ momorcharin extract of $M$. Charantia $(1000$ $\mu \mathrm{M}$, a high dose) alone or a combination of paclitaxel $(250 \mu \mathrm{g})$ with the $\alpha, \beta$ momorcharin extract of $M$. Charantia $(1000 \mu \mathrm{M})$ on the viability of the three different cancer cell lines and on healthy L6 skeletal muscle cell line employed in this study. Also shown in the figure 2 are the untreated three different cancer cell lines and healthy L6 skeletal muscle cell line for comparison. All the cells were treated with paclitaxel and $\alpha, \beta$ momorcharin extract of $M$. Charantia (drug + extract) for 24 hours. Control cell lines were also incubated for the same time. The results show that in all three different cancer cell lines $(1321 \mathrm{~N} 1$, Gos-3, U87-MG, ) either paclitaxel or $\alpha, \beta$ momorcharin extract of $M$. Charantia can evoked marked and significant $\mathrm{p}<0.05$ decreases in the cell viability (cell death) compared to untreated cells (100\% viability). However, when paclitaxel was com- 
bined with the $\alpha, \beta$ momorcharin extract of $M$. Charantia, there was a further decrease in cell viability. These values were significantly $(\mathrm{p}<0.05)$ different compared to either untreated cells $(100 \%)$ or cell treated with either paclitaxel or $\alpha, \beta$ momorcharin extract of $M$. Charantia.

Similarly, paclitaxel combined with the $\alpha, \beta$ momorcharin extract of $M$. Charantia can evoke significant ( $p$ $<0.05$ ) decrease in the death of healthy L6 skeletal muscle cell line. The results also show that combined drugs (drug + extract) were more effective in killing $1321 \mathrm{~N} 1$, Gos-3, cell lines. It has less effective on U87MG cell lines.

\section{Discussion}

This study employed the $\alpha, \beta$ momorcharin extracts of $M$. Charantia, and commercially available anti-cancer drugs paclitaxel to investigate their effects on the viability (cell death) of three different cancer cell lines compared to healthy L6 skeletal muscle cell line. Either the $\alpha, \beta$ momorcharin extract of $M$. Charantia, paclitaxel was tested alone measuring the viability of each cell line. In some experiments, paclitaxel was combined with $\alpha, \beta$ momorcharin extracts of $M$. Charantia, to investigate any potentiating or attenuating effect on cell viability. The rationale for this study was that $M$. Charantia, a local plants-base (herbal) medicine could be used to treat different types of cancers. The results of the present study have shown that either paclitaxel can significantly decrease the viability of $1321 \mathrm{~N} 1$, Gos-3, U87-MG, cancer cell lines. Both anti-cancer drugs also decreased the viability of healthy L6 skeletal muscle cell line. The effect of each drug was dose-dependent with maximal effect occurring at paclitaxel. The results of this study also show that combining a moderate to a high dose of paclitaxel with a high dose of either the $\alpha$, $\beta$ momorcharin extract of $M$. Charantia only produce a small, but significant decrease in the viability of each cancer cell line compared to the effect of paclitaxel and the $\alpha, \beta$ momorcharin extract of $M$. Charantia alone. This small decrease in cell viability of each cell line was slightly significant, but it was neither additive nor synergetic compared to the separate effect of each. This was a rather surprising result in this study.

\section{Conclusion}

In conclusion, the results of this study have clearly demonstrated that the $\alpha, \beta$ momorcharin extract of $M$. Charantia can evoke significant decreases in cancer cell viability (an increase in cell death) without killing healthy cell line like L6 skeletal muscle cell line. Either paclitaxel with maximal effect of paclitaxel can also elicit dose-dependent decreases in cancer cell viability. Combining paclitaxel with either the $\alpha, \beta$ momorcharin extract of $M$. Charantia had no additive or synergetic effect on the viability of each cell line compared to the effect of either alone. It is concluded that extracts of $M$. Charantia possess anti-cancer properties since they can induce cell death.

Acknowledgments: We gratefully acknowledge University of Central Lancashire for Science and technology for providing the financial support and required facilities to carry out this research work through a scientific research grant.

\section{References}

[1] Ahmed I, Sharma AK, Ponery AS, Bener A and Singh J. The influence of Momordica charantia on ultrastructural abnormalities of myelinated fibres in experimental diabetes. Int. J Diabetes. 1999; 7(1): 110-21.

[2] Licastro F, Franceschi C, Barbieri L and Stirpe F. Toicity of Momordica charantia lectin and inhibitor for human normal and leukaemic lymphocytes. Virchows Arch B Cell Pathol Incl Mol Pathol. 1980;33(6): 257-65.

[3] Zhu Z J. Studies on the active constituents of Momordica charantia. Yao Hsueh. Hsueh. 1990;25(3): 898-903

[4] Tsao SW, Ng TB and Yeung HW. Toxicities of trichosanthin and alpha-momorcharin, abortifacient proteins from Chinese medicinal plants, on cultured tumor cell lines. Toxicon. 1990; 28(4): 1183-1192.

[5] Asli S, and Alaattin S. Antioxidant and chemo protective properties of Momordica charantia L. (bitter melon) fruit extract. African Journal of Biotechnology. 2007;3(6): 273-7.

[6] Manoharan G and Singh J. The Anti-Diabetic Effects of Momordica Charantia: Active Constituents and Modes of Actions. The Open Medicinal Chemistry Journal. 2011;5(6) :70-7.

[7] Manoharan G and Singh J. Effect of $\alpha, \beta$ momorcharin on viability, caspase activity, cytochrome c release and on cytosolic calcium levels in different cancer cell lines. Molecular and Cellular Biochemistry. 2014;2(6): 4233-240.

[8] Moore MJ, Feld R, Hedley D, Oza A and Siu LL. A phase II study of temozolomide in advanced untreated pancreatic cancer. Invest New Drugs.1998;16(1):77-79.

[9] Manoharan G. Effects of Alpha and Beta Momorcharin Extract of Momordica Charantia in Intracellular Free Calcium on Cancer Cell Lines. (International Journal of Current Research in Physiology and Pharmacology. 2019; 3(1), 7-12.

[10] Brada M. NICE verdict on Temozolomide: where next? Br. J.Cancer. 2002 ;86(6):499-500

[11] Espinosa E, Zamora P, Feliu J and Baron MG. Classification of anticancer drugs- a new system based on therapeutic targets. Cancer treatment Reviews. 2003;29(11): 515-23.

[12] Schwartzbaum JA, Fisher JL, Aldape KD and Wrensch M. Epidemiology and molecular pathology of glioma. Nature Clinical Practice Neurology. 2006;2(6): 494-503

[13] Sun Y, Huang PL, Li JJ, Huang YQ, Zhang L, Huang PL and Lee-Huang S. Anti-HIV agent MAP30 modulates the expression profile of viral and cellular genes for proliferation and apoptosis in AIDS-related lymphoma cells infected with Kaposi's sarcoma-associated virus. Biochemical and Biophysical Research Communication. 
2001; 287(6): 983-94.

[14] Fewer D, Wilson CB, Boldrey EB, Enot KJ and Powell MR. The chemotherapy of brain tumors. Clinical experience with carmustine (BCNU) and vincristine. Jama. 1972; 222(6), 549-52

[15] Friedberg EC. How nucleotide excision repair protects against cancer. Nature Reviews Cancer. $2001 ; 1(6): 22-3$

[16] Tonn JC, Schachenmayr W and Kraemer HP. In vitro chemo sensitivity test of malignant gliomas: clinical relevance of test results independent of adjuvant chemotherapy. Anticancer Res.1994;14 (6):1371-5

[17] Sawyer JR, Swanson CM, Roloson GJ, Longee DC, Boop FA and Chadduck WM. Molecular cytogenetic analysis of a medulloblastoma with isochromosome 17 and double minutes. Cancer Genet.Cytogenet.1991;57(6):181-86.

[18] Schwartzbaum JA, Fisher JL, Aldape KD and Wrensch M. Epidemiology and molecular pathology of glioma. Nature Clinical Practice Neurology. 2006 ;2(6): 494-503.

[19] Omar S. Hypoglycemic effect of the seeds of Momordica charantia. Fitoterapia. 2007;78 (6):46-47

[20] Fong PC, Haynes LJ, Magnus KE and Plimmer JR. Pharmacological screening of some West Indian medicinal plants. Journal of Pharmacology.1996;14(7) :556-560. 